Article

\title{
Cold Science Meets Hot Weather: Environmental Threats, Emotional Messages and Scientific Storytelling
}

\author{
Rolf Lidskog *, Monika Berg, Karin M. Gustafsson and Erik Löfmarck
}

Environmental Sociology Section, School of Humanities, Educational and Social Sciences, Örebro University, 70182 Örebro, Sweden; E-Mails: rolf.lidskog@oru.se (R.L.), monika.berg@oru.se (M.B.), karin.m.gustafsson@oru.se (K.M.G.), erik.lofmarck@oru.se (E.L.)

* Corresponding author

Submitted: 27 August 2019 | Accepted: 17 December 2019 | Published: 18 March 2020

\begin{abstract}
Science is frequently called upon to provide guidance in the work towards sustainable development. However, for science to promote action, it is not sufficient that scientific advice is seen as competent and trustworthy. Such advice must also be perceived as meaningful and important, showing the need and urgency of taking action. This article discusses how science tries to facilitate action. It claims that the use of scientific storytelling-coherent stories told by scientists about environmental trajectories - are central in this; these stories provide meaning and motivate and guide action. To do this, the storylines need to include both a normative orientation and emotional appeals. Two different cases of scientific storytelling are analyzed: one is a dystopic story about a world rushing towards ecological catastrophe, and the other is an optimistic story about a world making dramatic progress. These macrosocial stories offer science-based ways to see the world and aim to foster and guide action. The article concludes by stating that using storylines in scientific storytelling can elicit fear, inspire hope, and guide action. The storylines connect cold and distant scientific findings to passionate imperatives about the need for social transformation. However, this attachment to emotions and values needs to be done reflexively, not only in order to create engagement with an issue but also to counteract a post-truth society where passionate imperatives go against scientific knowledge.
\end{abstract}

\section{Keywords}

Anthropocene; emotions; Factfulness; narratives; science communication; scientific storytelling; The Great Acceleration

Issue

This article is part of the issue "Emotions and Emotional Appeals in Science Communication" edited by Monika Taddicken (Technische Universität Braunschweig, Germany) and Anne Reif (Technische Universität Braunschweig, Germany).

(C) 2020 by the authors; licensee Cogitatio (Lisbon, Portugal). This article is licensed under a Creative Commons Attribution 4.0 International License (CC BY).

\section{Introduction: Constructing Knowledge that Matters}

Across diverse issues and domains, a new form of expertise has emerged with the task of synthesizing, translating, and communicating scientific knowledge to decision-makers, stakeholders, and the general public (Beck et al., 2014; Esguerra, Beck, \& Lidskog, 2017; Lidskog \& Sundqvist, 2015; Turnhout, Dewulf, \& Hulme, 2016). This expertise aims to guide and motivate action. A particular challenge for this kind of expertise is to synthesize and package knowledge in a way that makes it useful, credible, and meaningful for decision- makers (Gustafsson \& Lidskog, 2018; Heink et al., 2015). In this process, there is always a risk that the reduction of complexity-in order to make it a clear message that is understandable for nonexperts-will lead to criticism and a loss of credibility (Lidskog, Mol, \& Oosterveer, 2015). The scientific community may consider the simplifications to have gone too far and the public and stakeholders may express distrust and even use the reduction of complexity and uncertainty as a means for questioning the status of the knowledge claims, a strategy that the climate denialism movement has made ample use of (Dunlap \& McCright, 2015). 
The tension between being understandable and relevant without losing scientific credibility is further fueled by a current trend where science, apart from providing knowledge about an issue, is requested to assess possible solutions to that problem (Beck \& Mahony, 2018; Haas, 2017; Jabbour \& Flachsland, 2017). For a long time, the social sciences have stressed that messages need to be meaningful in order to influence an actor's thoughts and actions. Risk psychology stresses that cognitions and feelings affect the public's perception of risks (Slovic, 2010), risk sociology stresses that risks are always staged to conceal normative and epistemic assumptions (Hilgartner, 2000; Lidskog \& Sundqvist, 2013), and strands within policy studies and communication studies stress that meaning-making in public policy is done in the form of narratives and storylines (Bevir, 2011; Fairclough, 2013; Persson, 2015; Yanow, 2007). In different ways, the majority of this research address how organizations, such as media, policymakers, and corporate industry, frame and distribute messages and how different social segments appropriate these messages (Arnold, 2018). This article focuses on another kind of actor: that of scientific expertise. The reason for this focus is that despite much talk about a post-truth society and science skepticism, science still holds epistemic authority (Jasanoff, 2018; Lidskog \& Sundqvist, 2018). Scientists are often recognized as authoritative storytellers and legitimate constructors and disseminators of science-based stories. Thus, through their role as scientists, they give credibility to the storylines they spread. While most scientific advice tends to have a "rational bias" in the sense of paying limited attention to the importance of norms and emotions, the aim of this article is to show that there is an inevitable normative and emotive base in sciencebased narratives that aims to transform thoughts and initiate actions. This, we will argue, is the case even when the narratives state the ambition to create transformations and actions by "simply stating the facts," and it follows from the need to tell a compelling story in order to be heard and make an impression. By including not only factual information but also normative orientations and emotional appeals, scientific storytelling relates cold and distant scientific findings to passionate imperatives about the need for social transformation. At the same time, developing and communicating storylines is a complex task that puts the trustworthiness needed to make a story compelling at risk (Arnold, 2018). If the voice of expertise is deemed too normative and emotional, it may lose its epistemic authority-and the narrative may be reduced to an expression of opinion.

This article discusses a particular form of scientific communication: scientific storytelling aimed to facilitate action. By analyzing two different cases of scientific storytelling we will explore how scientists create storylines with the aim of disseminating a science-based worldview to a wider audience. What we are particularly interested in is how scientific storytelling connects to normative imperatives and emotional appeals. To examine this, we have chosen two different cases of successful outreach. The cases represent opposite views on the direction of current global development. Consequently, they also provide diverging guidance on how to act. The two cases are mainly used to explore how scientific storytelling relates to norms and emotions. The empirical material consists of original texts (including graphs and illustrations) that develop these storylines.

The article comprises six sections, including this introduction. The second section outlines the point of departure: the role of narratives and scientific storytelling in creating a public understanding of environmental issues. The third section presents the selection of cases and empirical materials. The fourth section describes the two selected cases of scientific storytelling, and the fifth section makes use of these cases to discuss the normative and emotive aspects of these storylines. The sixth and concluding section discusses the role of emotions in scientific storylines. The article concludes by stressing the importance of attaching to norms and emotions in a reflexive way in order to create engagement with an issue while at the same time avoiding a post-truth development in which passionate imperatives go against scientific knowledge.

\section{Narratives, Storylines, and Scientific Storytelling}

Storytelling is a fundamental element of all cultures, and human sciences (not least literature studies and religious studies) have analyzed the role and construction of stories in detail (Ricœur, 1995). The analysis of stories and narratives has also gradually been included in other disciplinary fields. In policy analysis, interpretative approaches (Bacchi, 1999; Fischer \& Forester, 1993; Yanow, 1996) and narrative approaches (Roe, 1994) have developed methods for analyzing how meaning is created in policy formation. Narrative policy analysts (Jones, McBeth, \& Shanahan, 2014) have developed a structured way to analyze policies and policy debates by stressing generalizable and context-independent elements of narratives, such as the setting, characters, plot, and moral of a story. Other policy analysts stress the important role of stories, metaphors, and symbols in the struggle over how a situation or a problem should be understood (Hajer, 1995). By means of how the problem is framed, stories, metaphors, and symbols serve to explain how the world works and to affect how actors relate to the world (Stone, 2012).

Interpretive policy studies focus on policy storylines and the function that scientific facts may play in them. These analyses have shown that scientific findings and facts often play an important role in the storylines that gain political influence, not least by lending them legitimacy (Fischer, 2003; Hajer, 1995; Lee, 2007; Stone, 2012). While the scientific communication that feeds into this process is not part of the analysis, the function of scientific components (such as causalities, concepts, or figures) in the policy narratives suggest that 
they are associated with neutrality and objectivity (see e.g., Stone, 2012). This view seems to be encompassed by some advocators of scientific storytelling, seeing it as a particular narrative form that serves the function of transferring scientific truths to nonscientific contexts (see e.g., Bickmore, Thompson, Grandy, \& Tomlin, 2009; Dahlstrom \& Scheufele, 2018). In this study, we focus on this scientific storytelling. That is, the communication of scientific knowledge and results that may then feed into policy storylines in different ways.

Science and technology studies (STS) has, for a long time, focused on the relation between science and policy in a more general way. STS stresses the fundamental role of co-production and that the epistemic and normative understandings of the world are intertwined in such a way that both representations of the world and normative ideals about how this world should be are constructed (Jasanoff, 2004; Wynne, 2005). In other words, STS scholars argue that fact-finding and meaning-making are intertwined and that scientific beliefs often are distributed widely in society, providing meanings for ideas and objects (Jasanoff, 2012, 2018). The implication is that science never merely describes the world but also tells what the right questions about this world are, e.g., which questions need to be raised to identify potential risks. However, how issues are (scientifically and technically) framed and what epistemic and normative assumptions lie behind this framing are often invisible to the public and taken for granted by scientists (Wynne, 2005). An implication of this is that many scientists tend to interpret diverging views between science and the public as caused by the public misunderstanding science; this is called "the deficit model," where the solution is to inform or even educate the public about scientific literacy (Irwin \& Wynne, 1996). Contrary to this, STS argues for greater reflexivity on the side of science about its own epistemic and normative underpinnings and an opening up of room for knowledge input from the public, which is called "the dialogical model." This contribution, with its stress on how science implicitly frames issues and influences public meanings, is very relevant for our study. However, what the discussion within STS is missing is, according to our view, a stronger focus on the role of emotions (Engdahl \& Lidskog, 2014). Risk psychology has stressed for a long time that feelings are a constitutive part of human judgment and decision-making and that feelings and cognition are interrelated (Finucane, 2013). Thus, focusing only on epistemic and normative issues in scientific storytelling gives a one-sided view of how science matters in framing issues and spreading them in society.

Scientific storytelling-which is the topic of this article-is the creation and sharing of science-based storylines that are told by scientists and aimed at influencing a wider audience and guiding action (Dahlstrom \& Scheufele, 2018; Kosara \& Mackinlay, 2013). In scientific storytelling, scientific concepts and measures are translated in order to be meaningful for people outside a particular scientific community (Latour, 1987; Lidskog, 2014). These kinds of storylines are often based on symbols, analogies, and emblematic issues in, for example, the form of formative events or indexes and graphs that summarize complex and broad processes of change (Stone, 2012). Typically, a storyline gives a historical account of the problem and its causes and consequences, which motivates, guides, and legitimizes decisions and actions. By telling not only what has happened and why but also what to do about the issue (explicitly or implicitly), scientific storytelling combines factual statements and a normative orientation in order to facilitate action. Successful storytelling not only explains the world but also motivates action, and a central means for this is emotionally engaging the listener (Arnold, 2018). As has long been stressed by rhetoric, an orator should include not only ethos and logos but also pathos (appeals to emotions); this is done in order to not only teach the public but also engage it.

\section{Case Selection and Empirical Material}

We selected two different cases of scientific storytelling to explore how scientists create storylines with the aim of disseminating a science-based worldview to a wider audience, thereby hoping to transform thoughts and initiate action. The Great Acceleration is part of the broader Anthropocene-narrative and is a largely dystopic story of a world rushing towards a global ecological catastrophe. In contrast, the narrative of Factfulness is substantially more optimistic, highlighting how the world is on the right track with dramatic global progress in many areas. These stories are told by scientists and other actors using wide brushstrokes, with the aim of changing worldviews, mindsets, and beliefs about what is desirable as well as possible to achieve. Thus, the cases are: 1) macrosocial stories about the trajectory of current society; 2 ) told by scientists; 3 ) claimed to be scientifically authoritative ways to understand the world; 4) aimed at changing worldviews and fostering action; and 5) distributed broadly in society.

These cases were also selected because they represent diametrically opposite views of the direction on current global development. Consequently, they also provide diverging normative guidance and evoke different emotional appeals, which make them of great interest to analyze together. They also differ in origin and in how the stories have been disseminated. Originally, The Great Acceleration was presented in a scientific context, and it has gradually been spread in different settings, reaching different groups. In contrast to this, Factfulness has directly targeted a wider audience through a broadly spread and popular scientific book, TED Talks, and a website with interactive materials.

The empirical material consists of primary sources such as written documents, including the graphs that illustrates these texts. The analysis of The Great Acceleration is based on the work of Steffen, Grinevald, 
Crutzen, and McNeill (2011) and Steffen, Broadgate, Deutsch, Gaffney, and Ludwig (2015). We also made a review of the broader Anthropocene narrative, which provided an interpretative frame for our understanding of The Great Acceleration (Lidskog \& Waterton, 2016, 2018). The analysis of Factfulness is based on a book of the same title (Rosling, Rosling, \& Rosling-Rönnlund, 2018). We also analyzed the biography How I Learned to Understand the World (Rosling, 2017), in which Hans Rosling describes how he developed the perspective of Factfulness and how he, together with his colleagues, established the Gapminder Foundation, which works to globally disseminate Factfulness.

The analysis of the two storylines began by mapping the two cases in terms of their problem descriptions, suggested solutions, and concept of role of the public, etc. (see also Table 1). In the next section, we specifically analyze how these two cases of scientific storytelling relate to norms and emotions.

\section{The Cases: Environmental Destruction versus Human Progress}

The storylines of The Great Acceleration and Factfulness construct stories about global development, distribute them to the public and stakeholders and, thereby, create incentives for action.

\subsection{Anthropocene and The Great Acceleration}

The Anthropocene narrative has made an amazing journey, from a spontaneous invention at a scientific conference in the year 2000 to a story that is now widely adopted and institutionalized within the scientific community (Crutzen \& Stoermer, 2000; Hamilton, 2017; Lidskog \& Waterton, 2016). The narrative has also successfully spread outside the scientific community, not only through environmental movements and governmental bodies but also through cultural institutions, such as museums and galleries, which have elaborated exhibitions and artistic performances (Robin et al., 2014). The concept's original meaning-a new geological epoch where human activities are geologically traceable-has been subordinated to a wider story of a human predica- ment where human impact now threatens fundamental life processes on earth. The narrative is dynamic and functions in many settings, however, most of its meaning is stabilized around a number of graphs labeled The Great Acceleration.

The Great Acceleration is a term that was coined to grasp a drastic increase in human polluting activities starting after World War II (Steffen et al., 2011, pp. 851-852, 2015, pp. 84-87). Twelve different indicators, such as human population, gross domestic product, fertilizer consumption, and water use, showed a dramatic increase and were then linked to major adverse environmental effects such as the concentration of carbon dioxide in the atmosphere, the global extinction of species, and ocean acidification (for an example, see Figure 1). The figure of The Great Accelerationalso labeled "the hockey stick" figure-has become an iconic symbol of the Anthropocene. The narrative claims that humanity has "switched gears" and is speeding up the tempo of growth, a shift that is identifiable through the rising trends of resource extraction and environmental emissions.

The narrative of The Great Acceleration is played an important part in making the Anthropocene a story that invokes fear, as it asserts that humanity is facing its greatest challenge ever and claims that there is a need for rapid and extensive societal changes to halt this trend. This need for a radical social transformation is a challenge not only for society in general but also for science, which has to produce relevant knowledge that facilitates and guides this transformation (Zalasiewicz, Williams, Steffen, \& Crutzen, 2010). However, the narrative of the Anthropocene also includes aspects of hope, stating that there is still time to act. In this narrative, there is the great challenge of balancing the dynamic between emotional messages of fear and hope in order to create story that opens up space and also provides incentives for action.

\subsection{Gapminder and Factfulness}

Gapminder is in independent foundation that aims to fight devastating misconceptions about global development by producing free teaching resources based on statistics (gapminder.org). Its innovative conversion of
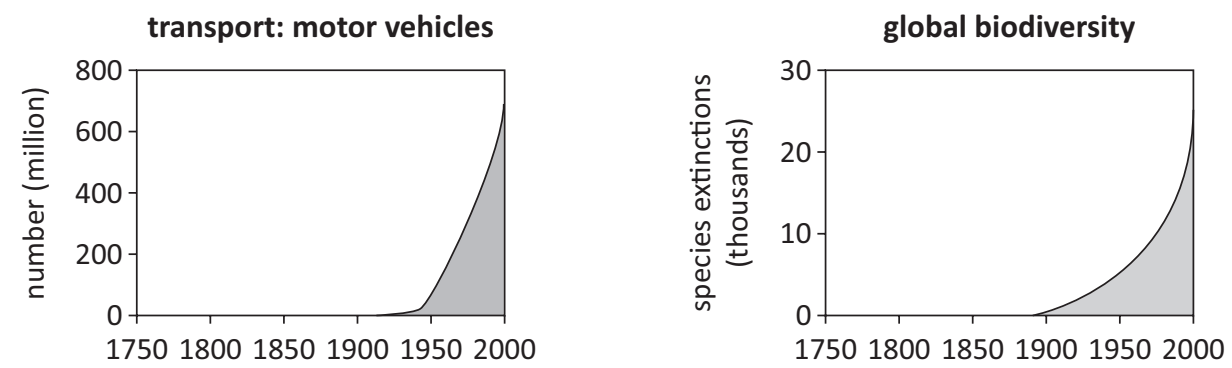

Figure 1. Examples of "The increasing rates of change in human activity since the beginning of Industrial Revolution" and "Global scale changes in the Earth system as a result of the dramatic increase in human activity." Note: See supplementary materials on the journal's website for all 24 graphs. Source: Steffen et al. (2011, pp. 851-852). 
quantitative data to animated and interactive graphics (such as bubble charts and scatterplots) has made the organization known to a broader public, and on its website, people can explore global trends in a number of areas. One of Gapminder's TED Talks, "The best statistics you've ever seen" (presented by one of its founders, Hans Rosling, in 2006), is still one of the most viewed TED talks ever, and the organization's ten TED Talks have together been seen by more than 35 million people.

Gapminder's essential storyline is that the world has become a better place to live in. This storyline is argued for by showing that in a number of fields - such as health, education, and welfare-global trends give a very clear picture of increasing health and welfare. Today, for example, there is no country with a life expectancy below 50 years, and the extreme poverty rate decreased from $50 \%$ in 1966 to $9 \%$ in 2017 . To show that these are broad positive trends, the narrative presents 32 improvements that show that the world is getting better (Rosling et al., 2018, pp. 60-63). First, it presents the decrease of 16 bad things concerning both human rights (such as legal slavery, infant mortality, and the death penalty) and the environment (such as oil spills from tanker ships, death from disasters, smoke particles, and ozone depletion). Second, the narrative also presents the increase of 16 good things concerning both life quality (such as literacy, democracy, and electricity coverage) and the environment (such as protected natural areas and monitored species).

Against this backdrop, it is argued that the vast majority of people have a distorted understanding of the world, believing that the world is poorer, less healthy, and more dangerous than it truly is (Rosling et al., 2018, p. 13). Thus, through his lectures around the world, Hans Rosling (Rosling et al., 2018) has found that most people have an inaccurate view of many of the measures that he uses to signify global development. Neglect of these numbers was found among audiences consisting of the general public as well as global elites-Nobel laureates, investment banks, and participants at the Davos World Economic Forum. Thus, even extremely well-educated people who deal with global issues in their professions were wrong about these aspects of global development.

\section{CHILDREN DYING}

Percent dying before their fith birthday

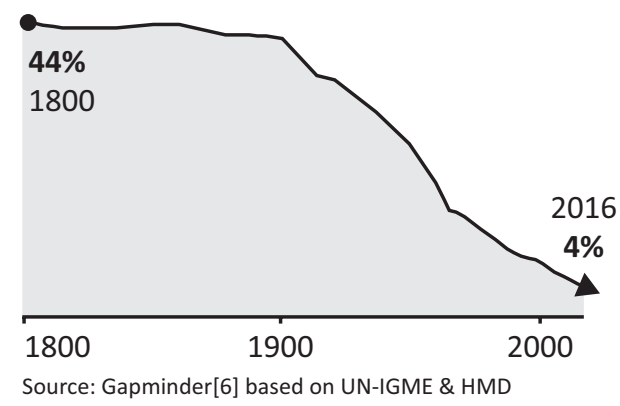

In the book Factfulness: Ten Reasons We're Wrong About the World-And Why Things are Better Than You Think, Rosling et al. (2018) seek to explain why people often have a wrong understanding of the world.

The book Factfulness has been translated into 30 languages and celebrated by a number of international celebrities. For example, Barack Obama has acclaimed it, and Bill Gates found it to be one of the most important books he had ever read, which prompted him to gift it to all new graduates of US colleges and universities one year (Gapminder, 2019a). The book was placed on the longlist for Business Book of the Year 2018 (Hill, 2018) and a review in Nature found it to be a magnificent book (O'Neill, 2018). The book explains that the reason we are getting the facts wrong is not ignorance or obsolete knowledge but rather preconceived ideas. It states that human beings carry ten instincts that distort our perspectives, making us blind to see global progress. According to Rosling et al. (2018), these instincts are evolutionarily grounded so that our brain gives precedence to dramatic information. This systematic misinterpretation results in an overdramatic worldview that leads to inappropriate focuses and bad decisions. Thus, the mission of Rosling and his colleagues is to eliminate the misguided perception of problems, thereby making space for focusing on real problems. The strategy that the narrative of Factfulness advocates is to widely spread information on these ten instincts and thereby let a fact-based worldview transform organizational and individual thinking. An implication of Factfulness is the moral imperative that we should only carry opinions that are based on solid facts. Consistent with this, Gapminder (2019b) presents itself not as a "think tank" but as a "fact tank."

\section{Analysis: Stories of Fear and of Hope}

Both The Great Acceleration and Factfulness are cases of scientific storytelling about the state of the world. They are both examples of a common type of narrative structure that evokes feelings of change (Stone, 2012, pp. 157-165). For The Great Acceleration, the direction of the change is decline and is attached to fear, whereas

\section{LITERACY}

Share of adults $(15+)$ with basic skills to

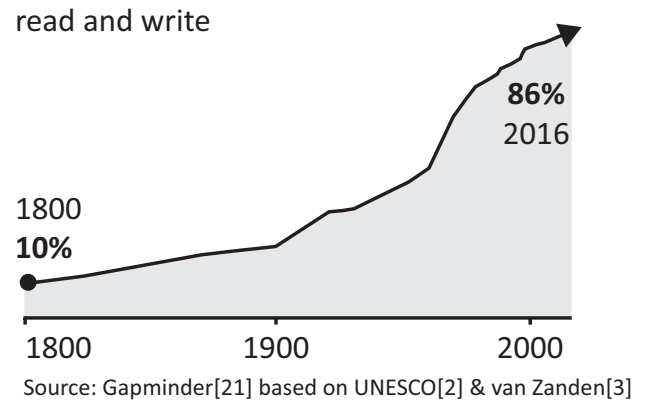

Figure 2. Examples of "bad things decreasing" and "good things increasing." Note: See supplementary materials on the journal's website for all 32 graphs. Source: Rosling et al. (2018, pp. 60-64). 
for Factfulness, the direction of change is progress and is attached to hope. They tell very different stories, guide listeners in diverging directions and invoke different emotions. Table 1 summarizes the main differences.

The two narratives have a number of differences and similarities. The most obvious similarity is their claim on epistemic authority and their belief in scientific facts. Both storylines claim to be based on established science and they share the mission of spreading a scientifically based understanding of the state of the world. Paradoxically, despite fighting for a scientific worldview, neither of them includes a scientifically grounded view-in terms of referring to the social and behavioral sciences-on society and human beings. In this sense, they are a paradoxical form of scientific storytelling that stresses the importance of science but ignores it when presenting social causes and remedies.

\subsection{Normative Guidance}

Both storylines aim to present the current state of the world and, at the same time, to guide the direction of action. They illustrate their messages by use of dramatic graphs, showing with great certainty the directions of global trends, and both storylines state that the graphs are based on authoritative sources. All the graphs they present (24 for The Great Acceleration and 32 for Factfulness) support their respective main messages, thereby creating a feeling of strong certainty about the direction society is heading in. By showing in this way that humankind is on the wrong or right track, they create reasons to act. They are, however, rather vague about who should act and how those actors should act in order to counteract or support current global trends. The storyline of The Great Acceleration clearly states that the current development towards environmental destruction urgently needs to be halted, but the narrative also develops little practical guidance about what to do (besides making sweeping statements about the need to change values, regulate growth, reduce consumption, etc.) and who should do it (the location of power and agency). The team behind Factfulness is very practical in describing how to avoid being steered by the ten human instincts that create an overdramatic and inaccurate worldview. By obtaining a fact-based worldview, we can "see that the world is not as bad as it seems-and we can see what we have to do to keep it making it better" (Rosling et al., 2018 , p. 255). At the same time, there is limited practical guidance given on what to do to make the world better. Instead, it seems as if science itself-"solid facts," as the narrative of Factfulness puts it (Rosling et al., 2018)-will give this guidance. By knowing the state of the world, it is believed that certain action will be taken or at least supported. In that sense, the storyline of Factfulness assumes that knowledge also gives direction, which goes against positivistic epistemology, which presumes a separation between "is" and "ought" and between facts and values. This also seems to be the case for The Great Acceleration, with its stress on scientific facts and scientific storytelling but with little discussion on which norms that should guide our actions.

Like many others, these storylines have a technocratic character in the sense they present the "true" nature of an issue and thereby conceal alternative views (Jasanoff, 2012; Wynne, 2005). Even if each storyline has a valid knowledge base for its views, scientific facts can be orchestrated differently; there are many ways to make facts part of a storyline's greater purpose. The contrasting images presented in these cases are a good illustration of this. The advocators of the Anthropocene probably do not question the figures and data that Gapminder disseminates but do not agree on the overall storyline and

Table 1. Comparison of the storylines of The Great Acceleration and Factfulness.

\begin{tabular}{|c|c|c|}
\hline & The Great Acceleration & Factfulness \\
\hline Main message & Things are getting worse! & Things are getting better! \\
\hline Focus & Environment & Health, welfare, environment \\
\hline Problem & $\begin{array}{l}\text { Ignorance at a level of severity that creates } \\
\text { low support for the needed action }\end{array}$ & $\begin{array}{l}\text { Overdramatic worldview that creates stress } \\
\text { and misguides action }\end{array}$ \\
\hline Solution & Getting the facts right & Getting the facts right \\
\hline Mission & Counteract environmental destruction & $\begin{array}{l}\text { Counteract unnecessary anxiety and thereby } \\
\text { focus on real-world problems }\end{array}$ \\
\hline The role of the public & $\begin{array}{l}\text { Mobilize public support for science-based } \\
\text { policies }\end{array}$ & $\begin{array}{l}\text { Educate people in order to help them to control } \\
\text { their instincts }\end{array}$ \\
\hline Norms & Not explicitly discussed & Not explicitly discussed \\
\hline Emotional appeal & Fear & Hope \\
\hline Imperative & Act now! & Don't overreact! \\
\hline View on emotions & Not discussed & Emotions as a problem \\
\hline
\end{tabular}


its projections about future development; this because they see the positive global trends that the narrative of Factfulness disseminates as based on exploiting earth's finite resources. Thus, the same trends that are used to support the Factfulness storyline of global progression in welfare are used by The Great Acceleration storyline to support trends towards the overconsumption that results in environmental degradation. An example of this is that the storyline of Factfulness (Rosling et al., 2018, pp. 62-63) sees the global increase of cellphones as "good things increasing," whereas The Great Acceleration associates the increased number of phones with environmental destruction (Steffen et al., 2011, p. 851). In this sense, both cases present an unproblematized storyline in the sense that they do not discuss their selection of the trends and why they attach specific meanings to the trends. The selection of numerous graphs where the factors follow the same development provides a crucial visual expression as well as emotional stimulation. Thus, their messages build on the multiplicity of graphs.

\subsection{Emotional Appeals}

While both storylines are science-based endeavors, they also work emotionally. The Great Acceleration is a feareliciting story, as it argues that in our quest for increased material wealth, we have come to a point where the fundamental life processes of the earth are threatened. In contrast to this, Factfulness provides a comforting and hope-inspiring story that argues that we are on the right track and that human progress takes place all over the world. Our worries about the state of the world, the narrative claims, are largely groundless and are caused by emotional responses. In this sense, both storylines believe that by presenting scientific facts, proper responses will be evoked. The storylines also validate certain emotions, in the sense that they claim that there are emotions of worry or hope that are scientifically grounded.

It is interesting to note that whereas the storyline of The Great Acceleration does not explicitly discuss emotions, the storyline of Factfulness has an ambiguous view. The latter states that critical thinking should replace our instinctive reactions, and then it uses emotionally laden and lively stories to replace hot feelings with cold facts. For example, the book Factfulness is filled with moving stories, Rosling's TED Talks appeal to our senses and are filled with entertaining moments, and Gapminder's software converts "boring" statistics on health and wealth into moving and colorful bubbles that spur interest and curiosity. An apposite example is how Hans Rosling once ended a talk by taking off his shirt, revealing to be black linen with gold sequins underneath, and then swallows a sword. By doing this, he aimed to show that what is seemingly impossible is possible; the sword-swallowing illustrated how wrong our intuitive beliefs are (see Rosling et al., 2018, pp. 1-3). In that sense, in contrast to their lack of presence in The Great Acceleration, emotions play a central role in Factfulness, which sees them as the main problem but also uses them to disseminate its core message to wider audiences.

\section{Discussion and Conclusion: Emotions Matter-Also for Science}

This article discusses a particular form of scientific communication: scientific storytelling that aims to facilitate action. The article claims that the development and distribution of compelling storylines-coherent stories about societal trajectories, including causes and possible futures-are central in this. To accomplish this, storylines need to include both a normative orientation and emotional appeals. Scientific storytelling generally aims to affect how we understand an issue as well as how we navigate in the world. To do that, the story told must be seen as trustworthy and worth acting upon (Wynne, 2005). It may stress an issue's importance (e.g., it is severity and need for urgent action) or deconstruct its importance (e.g., we are misguided and should focus on other, more important issues). In doing this, storylines connect to values and evoke emotions.

\subsection{Emotions in Science Communication and Knowledge Production}

It seems paradoxical to use emotional appeals to counteract emotions and instincts, but this is not necessarily the case. Scientific storytelling aims to change worldviews, and emotionally laden stories may be effective for this as a means for appropriating scientific facts. Using emotions as vehicles to persuade an audience is frequently effective: Emotionally laden stories can be used to pave the road for worldviews based on science and facts, as well as for other kinds of worldviews. However, it is important to not have an overly restricted view on emotions as effective instruments to change worldviews and behaviors. Such a view seems to be encompassed by some advocators of scientific storytelling who see it as a particular narrative form that facilitates the transfer of scientific truths to nonscientific contexts (see e.g., Bickmore et al., 2009; Dahlstrom, 2014; Dahlstrom \& Scheufele, 2018).

In contrast to this instrumental view on emotionsthat is, emotions as an important means for transferring knowledge but not having a relation to knowledge per se-many disciplines and research areas claim that emotions are anything but opposed to reason. Emotions can be rationally motivated in the sense that they are based on deeply held values-an idea that is stressed in moral philosophy, both by virtue ethicists (Nussbaum, 2013; Taylor, 1989) and deontological ethicists (Rawls, 1972). This is also in line with risk psychology (Slovic, 2010) and the sociology of emotions (Jacobsen, 2018; Turner \& Stets, 2005), which stress that emotions play an integral part in people's evaluations of claims of knowledge. Emotions are often discriminatory responses closely linked to an idea of what things are and what is important. Obviously, there are emotional responses that 
are irrational in the sense that they have no specific motivation (for example, feeling anger despite no injustice having been committed) and may hinder a broader understanding of an issue. However, the point is that emotions play an important role in knowledge processes, not only in the appropriation of knowledge but also in the production of it (Berlant, 2011; Schaefer, 2018). What we find worth knowing - as lay people as well as scientistsis always (partly) guided by our particular relations to the physical and social objects at stake. Thus, emotions are active on two levels: both in the shaping of scientific storylines and science communication and also in the knowledge production of science, guiding scientists in their scientific practices-as norms and values do. In this sense, emotions are constitutive not only for science communication and the public uptake of scientific knowledge but also for scientists' production of knowledge.

\subsection{Do Storylines Facilitate a Post-Truth Society?}

Cold and distant scientific findings combined with passionate imperatives may foster action. Storylines are decisive in this, eliciting fear, inspiring hope, and guiding action. At the same time, if the voice of science is seen as too normative or emotional, it may lose its scientific authority and be reduced to an expression of opinion. Thus, scientists face a complex balance in shaping persuasive storylines that involve normative guidance and emotional appeals but do not cause scientists to lose their epistemic authority. Finding the right amount of emotional appeal is indeed a difficult task. For instance, the message that "all is well" may lead to public complacency and inaction, e.g., when citizens come to view risk regulation as being well above the actual safety margins (Wang \& Kapucu, 2008). However, fear-eliciting messages may also trigger inaction, e.g., when the use of distressing imagery causes people to avoid or ignore persuasive messages (Brown \& Richardson, 2012).

There is also another danger when scientists are developing and disseminating storylines. By telling stories, scientific storytelling aims to mobilize people and organizations and guide their actions. However, other stories are also told, and there is a discursive struggle around which storyline should be considered true and gain political influence (Hajer, 1995). This is quite visible in the case of climate denialism. Think-tanks and anti-environmental organizations have created and disseminated (especially through social media) a storyline in which current environmental claims and initiatives for change are counteracted. Climate denialists have painted a picture of strong and far-reaching scientific disagreements and controversies about climate change that are being silenced by a global conspiracy favoring the discourse on climate change and obstructing critical voices, including scientific ones (Dunlap \& McCright, 2015; Oreskes \& Conway, 2010). Thereby, nonexperts have to navigate in a landscape populated by diverging storylines that all claim to be based on firm science (but also, as Norgaard, 2011, shows, involving strong emotional appeals). In this sense, much storytelling, including scientific storytelling, may foster a post-truth society in the sense that scientific storytelling is placed on the same level as other stories (Dahlstrom \& Scheufele, 2018). Thus, scientists are faced with a difficult dilemma here. If scientific storytelling, in its efforts to differ from other voices, includes discussions on epistemic assumptions, normative commitments, and views on emotions, the result may be less-compelling stories with limited spread and effects. Therefore, compelling stories are rarely stories that include a great amount of self-reflection and self-criticism. However, if scientific storytelling instead relies on a positivistic epistemology, believing that the storyline is solely based on unquestionable facts, it runs the risk of not fostering a science-based worldview in the sense of an unproblematized worldview with no room for complexity, contingency, and ambiguity.

In our opinion, this dilemma should not prevent researchers from developing storylines, which would only result in other storytellers populating this space (e.g., telling stories falsely claiming to be scientific, as is often the case with climate denialism). However, this dilemma means that scientists always have to reflect on how their storylines will be interpreted and what their wider consequences will be, not least how the storylines will affect the institutional trustworthiness of science. This is important because the perceived validity of scientific storylines is dependent on the trustworthiness of their sources, that is, whether the teller is seen to be representing an institution with epistemic authority.

In this sense, the general public, as well as scientific experts, need to cool down and reflect upon what kind of stories they are telling and listening to-and what the implications of such stories are. Reflexivity is needed, even when cold science is heating up to tackle global challenges.

\section{Acknowledgments}

We would like to thank the two anonymous reviewers as well as academic editors Monika Taddicken and Anne Reif for their valuable and constructive comments on an earlier version of this article.

\section{Conflict of Interests}

The authors declare no conflict of interests.

\section{Supplementary Material}

Supplementary material for this article is available online in the format provided by the author (unedited).

\section{References}

Arnold, A. (2018). Climate change and storytelling: Narratives and cultural meaning in environmental com- 
munication. Basingstoke: Palgrave.

Bacchi, C. L. (1999). Women, policy and politics: The construction of policy problems. London: SAGE.

Beck, S., \& Mahony, M. (2018). The IPCC and the new map of science and politics. WIREs Climate Change, 9(6), e547. https://doi.org/10.1002/wcc.547

Beck, S., Borie, M., Chilvers, J., Esguerra, A., Heubach, K., Hulme, M., ... Nadim, T. (2014). Towards a reflexive turn in the governance of global environmental expertise: The cases of the IPCC and the IPBES. GAIA: Ecological Perspectives for Science and Society, 23(2), 80-87. https://doi.org/10.14512/gaia.23.2.4

Berlant, L. G. (2011). Cruel optimism. Durham, NC: Duke University Press.

Bevir, M. (2011). Public administration as storytelling. Public Administration, 89(1), 183-195. https://doi. org/10.1111/j.1467-9299.2011.01908.x

Bickmore, B. R., Thompson, K. R., Grandy, D. A., \& Tomlin, T. (2009). Science as storytelling for teaching the nature of science and the science-religion interface. Journal of Geoscience Education, 57(3), 178-190. https://doi.org/10.5408/1.3544263

Brown, S. L., \& Richardson, M. (2012). The effect of distressing imagery on attention to and persuasiveness of an antialcohol message: A gaze-tracking approach. Health Education \& Behavior, 39(1), 8-17. https:// doi.org/10.1177/1090198111404411

Crutzen, P. J., \& Stoermer, E. F. (2000). The "Anthropocene." Global Change Newsletter, 2000(41), 17-18.

Dahlstrom, M. F. (2014). Using narratives and storytelling to communicate science with nonexpert audiences. Proceedings of the National Academy of Sciences, 111(Suppl. 4), 13614-13620. https://doi.org/ 10.1073/pnas.1320645111

Dahlstrom, M. F., \& Scheufele, D. A. (2018). (Escaping) the paradox of scientific storytelling. PLoS Biology, 16(10), e2006720. https://doi.org/10.1371/journal. pbio. 2006720

Dunlap, R. E., \& McCright, A. M. (2015). Challenging climate change: The denial countermovement. In R. Dunlap \& R. J. Brulle (Eds.), Climate change and society: Sociological perspectives (pp. 300-332). Oxford: Oxford University Press.

Engdahl, E., \& Lidskog, R. (2014). Risk, communication and trust: Towards an emotional understanding of trust. Public Understanding of Science, 23(6), 705-717. http://dx.doi.org/10.1177/ 0963662512460953

Esguerra, A., Beck, S., \& Lidskog, R. (2017). Stakeholder engagement in the making: IPBES legitimization politics. Global Environmental Politics, 17(1), 59-76. https://doi.org/10.1162/GLEP_a_00390

Fairclough, N. (2013). Critical discourse analysis and critical policy studies. Critical Policy Studies, 7(2), 177-197. https://doi.org/10.1080/19460171.2013. 798239

Finucane, M. L. (2013). The role of feelings in perceived risk. In S. Roeser, R. Hillerbrand, P. Sandin, \& M. Peterson (Eds.), Essentials of risk theory (pp. 57-74). New York, NY: Springer.

Fischer, F. (2003). Reframing public policy: Discursive politics and deliberative practices. Oxford: Oxford University Press.

Fischer, F., \& Forester, J. (Eds.). (1993). Argumentative turn in policy analysis and planning. Durham, NC: Duke University Press.

Gapminder. (2019a). Factfulness (the book). Gapminder. Retrieved from https://www.gapminder.org/ factfulness-book

Gapminder. (2019b). About Gapminder. Gapminder. Retrieved from https://www.gapminder.org/aboutgapminder

Gustafsson, K., \& Lidskog, R. (2018). Boundary organizations and environmental governance: Performance, institutional design, and conceptual development. Climate Risk Management, 19, 1-11. https://doi.org/ 10.1016/j.crm.2017.11.001

Haas, P. M. (2017). The epistemic authority of solutionoriented global environmental assessments. Environmental Science \& Policy, 77, 221-224. https://doi. org/10.1016/j.envsci.2017.03.013

Hajer, M. A. (1995). The politics of environmental discourse: Ecological modernization and the policy process. Oxford: Clarendon.

Hamilton, C. (2017). Defiant Earth: The fate of humans in the Anthropocene. Cambridge: Polity Press.

Heink, U., Marquard, E., Heubach, K., Jax, K., Hugel, C., Neßhöver, C., . . . Vandewalle, M. (2015). Conceptualizing credibility, relevance and legitimacy for evaluating the effectiveness of science-policy interfaces: Challenges and opportunities. Science and Public Policy, 42(5), 676-689. https://doi.org/10.1093/scipol/ scu082

Hilgartner, S. (2000). Science on stage: Expert advice as public drama. Stanford, CA: Stanford University Press.

Hill, A. (2018, August 13). Business book of the year 2018: The longlist. Financial Times. Retrieved from https://www.ft.com/content/47cff800-9a57-11e8ab77-f854c65a4465

Irwin, A., \& Wynne, B. (Eds.). (1996). Misunderstanding science? The public reconstruction of science and technology. Cambridge: Cambridge University Press.

Jabbour, J., \& Flachsland, C. (2017). 40 years of global environmental assessments: A retrospective analysis. Environmental Science and Policy, 77, 193-202. https://doi.org/10.1016/j.envsci.2017.05.001

Jacobsen, M. H. (2018). Emotions, everyday life and sociology. London: Routledge.

Jasanoff, S. (2004). The idiom of co-production. In S. Jasanoff (Eds.), States of knowledge: The coproduction of science and social order (pp. 1-12). London: Routledge.

Jasanoff, S. (2012). Science and public reason. New York, NY: Routledge. 
Jasanoff, S. (2018). Can science make sense of life? Cambridge: Polity Press.

Jones, M. D., McBeth, M. K., \& Shanahan, E. A. (2014). Introducing the narrative policy framework. In M. D. Jones, E. A. Shanahan, \& M. K. McBeth (Eds.), The science of stories (pp. 1-25). New York, NY: Palgrave.

Kosara, R., \& Mackinlay, J. (2013). Storytelling: The next step for visualization. Computer, 46(5), 44-50. https://doi.org/10.1109/MC.2013.36

Latour, B. (1987). Science in action: How to follow scientists and engineers through society. Cambridge, MA: Harvard University Press.

Lee, M. (2007). Inventing fear of crime: Criminology and the politics of anxiety. Cullompton: Willan.

Lidskog, R. (2014). Representing and regulating nature: Boundary organizations, portable representations and the science-policy interface. Environmental Politics, 23(4), 670-687. http://dx.doi.org/10.1080/ 09644016.2013 .898820

Lidskog, R., \& Sundqvist, G. (2015). When does science matter? International relations meets science and technology studies. Global Environmental Politics, 15(1), 1-20. https://doi.org/10.1162/GLEP_a_00269

Lidskog, R., \& Sundqvist, G. (2018). Environmental expertise as group belonging: Environmental sociology meets science and technology studies. Nature and Culture, 13(3), 309-331. https://doi.org/10.3167/nc. 2018.130301

Lidskog, R., \& Sundqvist, R. (2013). Sociology of risk. In S. Roeser, R. Hillerbrand, P. Sandin, \& M. Peterson (Eds.), Essentials of risk theory (pp. 75-105). New York, NY: Springer.

Lidskog, R., \& Waterton, C. (2016). Anthropocene: A cautious welcome from environmental sociology? Environmental Sociology, 2(4), 395-406. http://dx.doi. org/10.1080/23251042.2016.1210841

Lidskog, R., \& Waterton, C. (2018). The Anthropocene: A narrative in the making. In M. Boström \& D. Davidson (Eds.), Environment and society: Concepts and challenges (pp. 25-46). Basingstoke: Palgrave.

Lidskog, R., Mol, A., \& Oosterveer, P. (2015). Towards a global environmental sociology? Legacies, trends and future directions. Current Sociology, 63(3), 339-368. http://dx.doi.org/10.1177/0011392114543537

Norgaard, K. M. (2011). Living in denial: Climate change, emotions, and everyday life. Cambridge, MA: MIT Press.

Nussbaum, M. C. (2013). Political emotions: Why love matters for justice. Cambridge, MA: Belknap Press.

O’Neill, J. (2018). Swansong of Hans Rosling, data visionary. Nature, 556, 25-26. https://doi.org/10.1038/ d41586-018-03921-y

Oreskes, N., \& Conway, E. M. (2010). Merchants of doubt: How a handful of scientists obscured the truth on issues from tobacco smoke to global warming. New York, NY: Bloomsbury Press.

Persson, M. (2015). A policy problem that cannot escape its past constraints on the reformation of safety pol- icy. Critical Policy Studies, 9(2), 158-176.

Rawls, J. (1972). A theory of justice. Oxford: Clarendon.

Ricœur, P. (1995). Figuring the sacred: Religion, narrative, and imagination. Minneapolis, MN: Fortress Press.

Robin, L., Avango, D., Keogh, L., Möllers, N., Scherer, B., \& Trischler, H. (2014). Three galleries of the Anthropocene. The Anthropocene Review, 1(3), 207-224. https://doi.org/10.1177/2053019614550533

Roe, E. (1994). Narrative policy analysis: Theory and practice. Durham, NC: Duke University Press.

Rosling, H. (2017). Hur jag lärde mig förstå världen [How I learned to understand the world]. Stockholm: Natur \& Kultur.

Rosling, H., Rosling, O., \& Rosling-Rönnlund, A. R. (2018). Factfulness: Ten reasons we're wrong about the world-And why things are better than you think. London: Sceptre.

Schaefer, D. (2018). Beautiful facts: Science, secularism, and affect. In J. Corrigan (Ed.), Feeling religion (pp. 69-91). Durham, NC: Duke University Press.

Slovic, P. (2010). The feeling of risk: New perspectives on risk perception. London: Earthscan.

Steffen, W., Broadgate, W., Deutsch, L., Gaffney, O., \& Ludwig, C. (2015). The trajectory of the Anthropocene: The Great Acceleration. The Anthropocene Review, 2(1), 81-98. https://doi.org/10.1177/ 2053019614564785

Steffen, W., Grinevald, J., Crutzen, P., \& McNeill, J. (2011). The Anthropocene: Conceptual and historical perspectives. Philosophical Transactions of the Royal Society A, 369(1938), 842-867. https://doi.org/ $10.1098 /$ rsta.2010.0327

Stone, D. (2012). Policy paradox: The art of political decision making (3rd ed.). New York, NY: W.W. Norton \& Co.

Taylor, C. (1989). Sources of the self: The making of the modern identity. Cambridge, MA: Cambridge University Press.

Turner, J. H., \& Stets, J. E. (2005). The sociology of emotions. New York, NY: Cambridge University Press.

Turnhout, E., Dewulf, A., \& Hulme, M. (2016). What does policy-relevant global environmental knowledge do? The cases of climate and biodiversity. Current Opinion in Environmental Sustainability, 18, 65-72. https://doi.org/10.1016/j.cosust.2015.09.004

Wang, X., \& Kapucu, N. (2008). Public complacency under repeated emergency threats: Some empirical evidence. Journal of Public Administration Research and Theory, 18(1), 57-78. https://doi.org/10.1093/ jopart/mum001

Wynne, B. (2005). Risk as globalizing 'democratic' discourse? Framing subjects and citizens. In M. Leach, I. Scoones, \& B. Wynne (Eds.), Science and citizens: Globalization and the challenge of engagement ( $\mathrm{pp}$. 66-82). London: Zed Books.

Yanow, D. (1996). How does a policy mean? Interpreting policy and organizational actions. Washington, DC: Georgetown University Press. 
Yanow, D. (2007). Interpretation in policy analysis: On methods and practice. Critical Policy Studies, 1(1), 110-122. https://doi.org/10.1080/19460171. 2007.9518511
Zalasiewicz, J., Williams, M., Steffen, W., \& Crutzen, P. (2010). The new world of the Anthropocene. Environment, Science \& Technology, 44(7), 2228-2231. https://doi.org/10.1021/es903118j

\section{About the Authors}

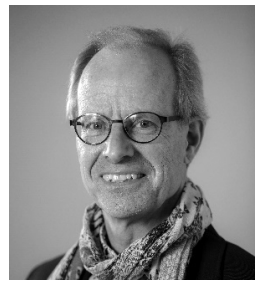

Rolf Lidskog (PhD) is Professor of Sociology at the Environmental Sociology Section, School of Humanities, Educational and Social Sciences, Örebro University. His research concerns environmental policy and politics, especially the role of expertise in environmental politics. Currently, he is conducting research on the epistemic and social conditions for expertise and its role in international environmental governance.

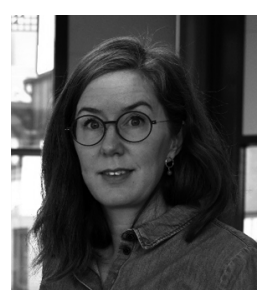

Monika Berg (PhD) is a Senior Lecturer in Sociology, the Environmental Sociology Section, School of Humanities, Educational and Social Sciences, Örebro University. Her main research interests are the role of knowledge in environmental governance and organizational prerequisites for sustainable transformations. Currently, she is conducting research on ethical dilemmas relating to sustainable development and how they are managed within public administration.

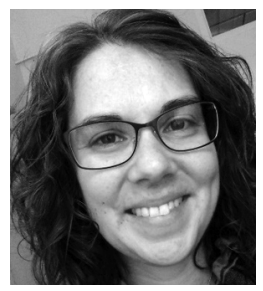

Karin M. Gustafsson (PhD) is an Associate Professor in Sociology, the Environmental Sociology Section, School of Humanities, Educational and Social Sciences, Örebro University. Her research primarily focuses climate change and biodiversity issues in the fields of environmental sociology, the sociology of knowledge, and science and technology studies. She is currently studying the role of science in international environmental governance and international expert organizations' socialization of young scholars.

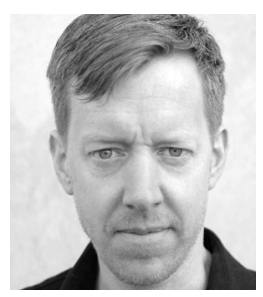

Erik Löfmarck (PhD) is a Senior Lecturer in Sociology, the Environmental Sociology Section, School of Humanities, Educational and Social Sciences, Örebro University, Sweden. His research concerns the social aspects of risk, knowledge, and the environment. Currently, he is exploring the role of indigenous local knowledge in knowledge assessments within environmental governance. 